\title{
EXPECTATIONS OF PROFESSIONALS IN THE TURKISH STOCK MARKET: A STUDY OF A MONTHLY REUTERS SURVEY*
}

\author{
M. NUMAN ÜLKÜ** \\ Central European University
}

\begin{abstract}
Reuters-Turkey News Service conducted a monthly survey of forecasts of the senior analysts, portfolio managers, or strategists of the major brokerage houses in the Istanbul Stock Exchange on the next month's closing level of the ISE-100 index. The survey data are analyzed in this study, in order to assess the forecasting performance of market professionals, to test previously documented behavioral biases of analyst expectations and some specific hypotheses of the noisy rational expectations literature. The results suggest that: i) survey participants' forecasts have no significant predictive power, ii) they exhibit optimism bias, iii) they tend to extrapolate from the past despite the fact that the degree of extrapolation is negatively correlated with forecast performance, iv) extrapolation is insignificant when the previous period's return is negative, $v$ ) there is little evidence of persistence in the forecasting performance over time, and vi) participants seem to place greater weight on market price than on their priors.
\end{abstract}

Key words: forecasting stock market monthly returns, forecast performance, behavioral biases in analyst expectations, emerging markets.

\section{TÜRKIYYE HISSE SENEDİ PIYASASINDA PROFESYONELLERIN BEKLENTILERI: REUTERS ANKETİ ÜZERINE BİR ÇALIŞMA}

ÖZET

Reuters Türkiye Haber Servisi, Ocak 2002 - Mart 2005 döneminde IMKB'deki aracı kurumların kıdemli analistleri, portföy yöneticileri veya stratejistleri arasında, IMKB-100 indeksinin ayllk kapanıs seviyesini tahmin anketi düzenlemiştir. Bu çalışmada, bu anket verileri, piyasa profesyonellerinin öngörü̈performansını ölçmek, analistlerin literatürde konu edilen davranışsal yanlılıklarını ve gürülttülü rasyonel beklentiler literatüründeki bazı hipotezleri test etmek amacryla analiz edilmektedir. Sonuçlar: i) ankete katılanların tahminlerinin öngörü gü̈ü̈ taşımadı̆̆̆ını, ii) aşırı iyimserlik yanlılı̆̆̆ taşıdığını, iii) öngörü performansını olumsuz etkilemesine ră̆men, öngörülerin geçmiş trendlerin devam edece ğ

* The author is thankful to Güzin Övünç and Reuters Turkey News Service for sharing the survey data. The views expressed here are those of the author and cannot be associated with Reuters. The author is also thankful to the participants of the 11th Annual Conference of the Multinational Finance Society in Istanbul, the editor and an anonymous referee for helpful comments.

** M. Numan Ülkü is an Associate Professor at the Central European University Business School, 1023, Budapest, Frankel Leo ut 30-34, Hungary. E-mail: ulkun@ ceubusiness.org

Boğaziçi Journal Vol. 22, no. 1-2 (2008), pp. 1-16. 
varsayımı ile oluşturulduğunu, iv) ancak önceki ayın getirisi negatif olduğunda geçmiş trendin devamı varsayımıyla öngörü oluşturma eğiliminin belirgin olmadı̆̆ını, v) öngörü performansının zaman içinde istikrarlı olduğunu söyleyebilecek bulgu elde edilemediğini, vi) katılımcıların piyasa fiyatının verdiği sinyallere kendi ön fikirlerinden daha fazla ă̆ırlık verme eğiliminde olduklarını göstermektedir.

Anahtar kelimeler: aylı hisse senedi indeks getirilerinin öngörülmesi, öngörü performansı, analist beklentilerinde yanlılıklar, gelişmekte olan piyasalar.

The Reuters-Turkey News Service conducted a monthly survey of forecasts of the senior analysts, portfolio managers, and strategists of the major brokerage houses in the Istanbul Stock Exchange (ISE) on the following month's closing level of the ISE-100 stock index, between January 2002 and March 2005. This unique data set provides us an opportunity to assess the predictive performance of professional market participants, to test behavioral hypotheses on analyst expectations, and to examine some of the extant hypotheses in the noisy rational expectations literature. The purpose of the paper is to add to the literature on stock market forecasting and analyst expectations by analyzing this real-life survey data from an emerging market setting. While results pertaining to forecasting performance are generally consistent with previous findings, those pertaining to behavioral hypotheses on analysts' expectations are noteworthy.

\section{LITERATURE REVIEW}

The efficient markets theory predicts that no forecaster should have the ability to consistently predict future returns, if the market is efficient. Evidence from early empirical studies tended to support this basic prediction (Fama, 1970). However, more recent literature of the last two decades contains a larger number of predictability findings. Stock index returns, the focus of this paper, are found to have predictable components from past returns (Fama and French, 1988), or from technical analysis signals (Brock et al., 1992).

This evidence, inconsistent with market efficiency, is obtained, however, in ex-post studies. More direct evidence should come from ex-ante forecasts of real-life market participants. For this reason, studies on the performance of market forecasters and portfolio managers have been part of the literature testing the efficient markets theory. The earliest example was Cowles (1934), who found that most of the forecasting effort was unsuccessful. See especially Hartzmark (1991), who found that superior performers are fewer than that would be expected under pure chance and that above-average performance is not correlated over time. The performance of mutual fund managers presents similar results (e.g., Bollen and Busse [2004] found that the persistence in superior performance is shortlived). In sum, the available evidence suggests little persistent predictive ability on the part of market professionals. These studies, taken together, are consistent with market efficiency and imply that the predictability found in ex- post tests could not have been utilized by real-life practitioners persistently, at least by an average of those sampled in the studies.

Another area of interest in analysts' forecasts stems from behavioral hypotheses. Lakonishok, Shleifer and Vishny (1994) explain the profitability of value strategies by extrapolation. Dechow and Sloan (1997), on the other hand, find that stock prices appear to reflect analysts' biased forecasts of future earnings growth rather than the naive extrapolation of past trends. These studies open up the need for 
further tests of biases in analysts' expectations, especially the tendency to extrapolate from the past. While one way of conducting such tests is experimental settings (see DeBondt, 1993; and on Turkish subjects, Muradoğlu, 2002), the transferability of findings from experimental designs to real-life pose some problems. Direct surveys with real-life agents may overcome some such shortcomings.

Another behavioral bias documented in the literature is systematic optimism. Dechow and Sloan (1997) report that over their 15-year I/B/E/S sample with 70,000 earnings forecasts per analyst per quarter per company, the mean forecast earnings growth rate was $14 \%$ while the mean rate of realized earnings growth was $8 \%$. This suggests that analysts systematically overestimate expected earnings. See also a more detailed study by Easterwood and Nutt (1999), who differentiate between systematic misreaction and systematic optimism, and provide results consistent with the latter. In the context of company earnings estimates, systematic optimism bias has often been related to agency issues. It will therefore be interesting to see whether the optimism bias holds in the context of market index forecasting where no agency issues are present.

Finally, the noisy rational expectations literature contains several premises and findings that need to be tested in more real-life settings. Market models tend to move from simple structures with uniform information (e.g., Grossman and Stiglitz, 1980; and Kyle, 1985) to complex structures with heterogeneous information (e.g., Foster and Viswanathan, 1996) where agents can infer information from the market price (Grundy and McNichols, 1989). As the results obtained do differ, there is need for more empirical tests to determine what assumption is valid in contemporaneous financial markets. One such issue is the heterogeneity of expectations: MacDonald and Marsh (1996), for example, find that "currency forecasters have heterogeneous expectations" and "such disagreements are the key variables in determining market trading volume." More empirical studies are needed to characterize the valid structure of expectations as well as to test the hypothesized relationships between the degree of conditional heterogeneity and the conditional variances and trading volumes. Another area of interest is the hypothesized role of prices as aggregators of private information (see Cho and Krishnan, 2000).

The next section describes the data and methodology. Following that, the results are discussed, and in the final section, the main conclusions are summarized.

\section{DATA AND METHODOLOGY}

The forecast of each participant is obtained on the last trading day of the preceding month. The deadline is market closing time, so that informational symmetry among participants is ensured. Survey results are announced on the same day shortly after market closing as a news headline on Reuters screens. ${ }^{(1)}$

The survey consisted of a single number representing the participants' point forecasts of the following month's closing level of the ISE-100 index. The survey was first implemented at the end of December, 2001, so the first survey data available are for January 2002. Reuters concluded the survey in March 2005, when 37 months of data had accumulated. ${ }^{(2)}$

While participants were kept anonymous during the first nine months of the survey, they were publicized in the name of the brokerage house from October 2002. ${ }^{(3)}$ This change of procedure was proposed by the author of this paper to prevent strategic behavior (i.e., submitting a forecast, which, 
if actualized, would benefit the participant), as participants representing their institutions would be expected to do their best. It had little impact on mean forecast errors: under anonymity, the average absolute error was slightly larger than the median absolute error (12.94\% vs. $12.70 \%)$; with publicity, the average was slightly smaller than the median (9.43\% vs. $9.44 \%)$. The difference between the behavior of the mean and median was consistent with some degree of strategic behavior, but had little impact on overall results. ${ }^{(4)}$

The number of participants per survey ranged between 13 and 22. Fourteen out of them had an attendance rate of $60 \%$ or higher. The remaining 15 with lower attendance rates were excluded in the performance analysis, but included in the computation of average/median expectations as they were unbiased observations. The discontinuity of participants mostly reflects discontinuity in the relevant position. Missing forecasts are mostly a result of temporary absences, hence not likely to distort the results. A few participants transferred from one institution to another, continuing the survey; in such cases, we treated the analyst rather than institution as the unit of observation. The average response rate per survey (number of replied/number of asked at each month) was around 80\%, which is high compared to similar surveys done with financial market professionals. This is probably because the survey was conducted with volunteers willing to exhibit or challenge forecast ability, their primary job task.

Forecast closing levels were first transformed into forecast returns. For each month, the representative forecast was computed by taking both the simple average and the median (to avoid the impact of outliers) of the forecasts of individual participants.

Strategic behavior has always been an issue in surveys where results are made publicly available. Even if one can assume that participants are rational enough to consider that their forecasts would have little impact on the equilibrium price in an efficient market and the loss of prestige as a result of bad forecasts would be far more costly, there is another reason to believe that the forecasts are biased toward the trading positions already held by participants: wishful thinking (i.e., assigning a higher probability to a desirable event than its true probability). While the publicity of his/her institution and the consequent competition are incentives for a participant to do his/her best, they may not guarantee it. Yet, the bias toward already held trading positions is not something to be avoided from the researcher's point of view, rather it enhances the link between what people say and what they do. The chronological order, however, must be taken into account here: To the extent that current forecasts are biased toward already held positions, they will reflect action that must have been already taken in the recent past, rather than to be taken in the future. These ideas will help in interpreting the results.

ISE-100 index and volume data are obtained from data vendor Euroline, which redistributes data from the ISE.

To present some descriptive statistics, the mean realized monthly raw return of the ISE-100 index over the 37-months sample period is 0.0184 , while the sample standard deviation is 0.1131 . The monthly realized raw returns of the ISE-100 index over the sample period can be seen in Figure 1 . The time-series mean of average (median) forecast return is $0.0561(0.0585)$ and the time-series sample standard deviation of average (median) forecasts is 0.0421 (0.0425). The ADF test rejects the unit root for monthly realized returns at all conventional levels of significance, and autocorrelation function does not contain significant coefficients at any lag. The Jarque-Bera test does not reject the normal distribution of returns over the sample period. While the variance of the index returns decreases in 
the later parts of the sample, this does not translate into heteroscedasticity in the regression analysis. Hence, OLS can safely be employed in the analysis below.

Figure 1

The Monthly Realized Raw Returns of the ISE-100 Index over the Sample Period

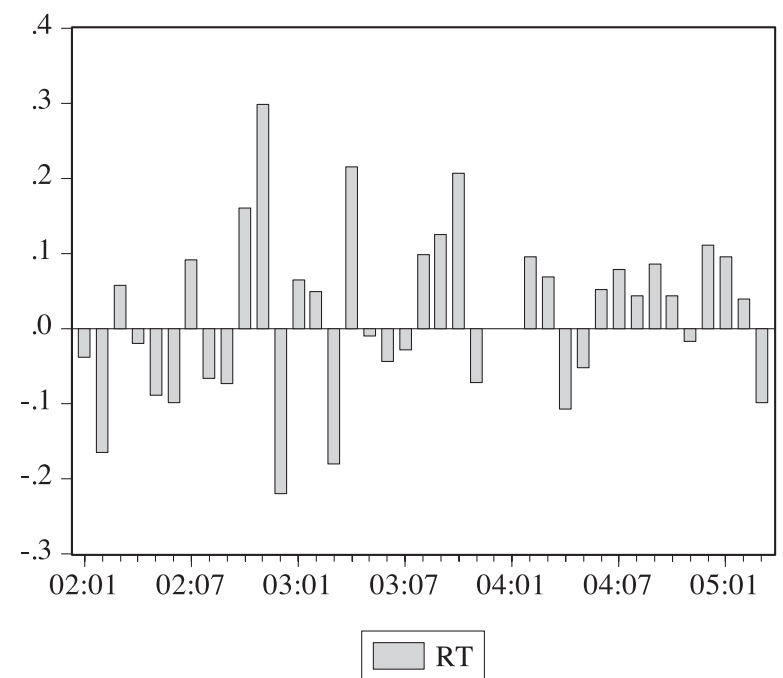

RESULTS

\section{The Forecasting Performance}

The forecasting performance of all participants as a group is assessed by the relation between median forecast returns and realized returns of the ISE-100 index. The results with simple average forecast returns are similar and not reported here. Let us notate the realized raw return of the ISE-100 index in month $t$ as $\mathrm{R}_{\mathrm{t}}$ and median forecast return for month $\mathrm{t}$ as $\mathrm{FR}_{\mathrm{t}}$. The following simple linear regression is run:

$$
R_{t}=a+b F R_{t}+e_{t}
$$

The forecasting ability of the median forecast is assessed simply by testing the null hypothesis that $\mathrm{b}=0$. The null hypothesis that $\mathrm{b}=0$ (i.e., that there is no statistical relation between forecast and realized returns) cannot be rejected at a $10 \%$ level; in fact, $\mathrm{F}=0.16$ and sig $(\mathrm{F})=0.69$ which is far from any significance. $\mathrm{R}^{2}$ is 0.004 . The clear conclusion is that median forecast does not have any significant predictive ability. The time-series average of absolute median forecast error is $10.24 \%$, which is comparable to the standard deviation of monthly returns. Additional inspection by subperiods suggests that the market's absolute forecast error tends to move together with the volatility of realized returns; hence, the improvement in the later parts of the sample can be attributed to a decrease in return volatility. ${ }^{(5)}$

As a robustness check, the ability of the median forecast to predict the return of the first half of the month and the average index level over the month (rather than at the end of the month) is investigated in order to account for the possibility that even though median forecast has some predictive ability under the current information set, unforeseen events later in the month make them obsolete. The 
results, though slightly stronger, are still far from significance. The null hypothesis " $b=0$ " cannot be rejected at a $10 \%$ level under any of these alternative definitions of the dependent variable (i.e., forecast month's realized return).

Further robustness checks suggest that the results are not driven by outliers. Missing forecasts generally result from non-strategic reasons such as absence, vacation, position change, etc., so that we can assume their impact on the results are random.

As for the performance of individual participants, the same regression is run separately for each of the 14 participants with an attendance rate $60 \%$ or higher. ${ }^{(6)}$ Let's notate the forecast of participant i for month $t$ as $\mathrm{FR}_{\mathrm{t}}^{\mathrm{i}}$.

$$
R_{t}=a^{i}+b^{i} F R_{t}^{i}+e_{t}^{i}
$$

Table 1

The Forecasting Performance of Individual Participants

\begin{tabular}{|c|c|c|c|c|c|c|}
\hline Participant & $\mathbf{n}$ & $\mathbf{b}^{\mathbf{i}}$ & sig (b) & $\mathbf{a}^{\mathrm{i}}$ & sig (a) & $\begin{array}{c}\text { Mean Abs. } \\
\text { For.Err }\end{array}$ \\
\hline 1 & 35 & -0.055 & 0.75 & 0.016 & 0.47 & 0.100 \\
\hline 2 & 22 & 0.146 & 0.52 & -0.004 & 0.91 & 0.147 \\
\hline 3 & 31 & -0.272 & 0.14 & 0.019 & 0.4 & 0.134 \\
\hline 4 & 34 & -0.107 & 0.54 & 0.025 & 0.41 & 0.135 \\
\hline 5 & 33 & 0.035 & 0.85 & 0.014 & 0.61 & 0.117 \\
\hline 6 & 26 & 0.159 & 0.44 & 0.009 & 0.75 & 0.118 \\
\hline 7 & 27 & -0.111 & 0.58 & 0.010 & 0.71 & 0.153 \\
\hline 8 & 25 & 0.223 & 0.28 & -0.009 & 0.7 & 0.127 \\
\hline 10 & 31 & 0.099 & 0.60 & 0.006 & 0.84 & 0.115 \\
\hline 11 & 26 & -0.192 & 0.54 & 0.020 & 0.46 & 0.122 \\
\hline 12 & 27 & -0.120 & 0.65 & 0.052 & 0.10 & 0.118 \\
\hline 13 & 32 & -0.177 & 0.28 & 0.008 & 0.73 & 0.098 \\
\hline 14 & 33 & 0.555 & 0.73 & 0.017 & 0.56 & 0.108 \\
\hline 15 & 30 & 0.312 & 0.42 & 0.018 & 0.52 & 0.109 \\
\hline Median & 37 & 0.067 & 0.69 & 0.008 & 0.80 & 0.122 \\
\hline \multicolumn{7}{|c|}{ Selected } \\
\hline 9 & 18 & 0.117 & 0.64 & 0.004 & 0.93 & 0.122 \\
\hline 16 & 14 & 0.495 & 0.07 & 0.032 & 0.11 & 0.061 \\
\hline 17 & 16 & 0.374 & 0.15 & -0.017 & 0.68 & 0.061 \\
\hline 18 & 10 & -0.300 & 0.40 & -0.011 & 0.86 & 0.113 \\
\hline
\end{tabular}

$\mathrm{n}$ is the number of months the participant attended the survey. $\mathrm{b}^{\mathrm{i}}$ is the estimated coefficient of forecast return in Equation 2. Sig (b) is the significance level of rejecting the null hypothesis " $b^{i}=0 "$ ". $a^{i}$ is the estimated constant in Equation 2. Mean.Abs.For.Err. is the simple average of each participant's absolute forecast error over the months. 
The results are presented in Table 1 . Forecast ability is assessed by testing the null hypothesis " $b^{i}=0 "$. The results suggest that the null hypothesis cannot be rejected at a $10 \%$ level for any of the 14 participants. The coefficients for six participants are negative. The mean absolute forecast error of the "best" participant is $9.8 \%$, and those of the other participants range between $10.0 \%$ and $15.3 \%$. ${ }^{(7)}$ The overall result is that none of participants has a statistically significant predictive ability over the one-month horizon. The distribution of the $b_{i}$ coefficients is close to what would be expected by pure chance (i.e., if all participants were forecasting randomly).

Another way of assessing forecast performance is to compare the mean absolute forecast errors of participants to a random walk model's mean absolute forecast error. ${ }^{(8)}$ Using a simple random walk model of $R_{t}=\mu_{t}+e_{t} \quad$ where $\mu_{t}$ is the trailing mean return over the past $n$ months $(n=37)$ and $e_{t}$ is i.i.d., the mean absolute error is 0.092 . This is lower than the mean absolute forecast error of the "best" participant. In other words, all of the 14 participants produced larger errors than a simple random walk model, suggesting that they would have performed better had they been forecasting randomly.

As in Hartzmark (1991), the persistence in performance is assessed by dividing the sample into two halves. The ranking of participants according to average absolute forecast error, presented in Table 2, suggests that, as in Hartzmark (1991), there is little evidence of persistence in the forecast performance of individual participants across time: Most of the best performers of the first half are below average in the second half, while average and worse performers of the first half seem somewhat more stable. This is consistent with Hartzmark's conclusions, at least in the sense that forecasters do not have the ability to sustain above-average performance in changing market conditions.

Table 2

The Ranking of Participants according to Average Absolute Forecast Error

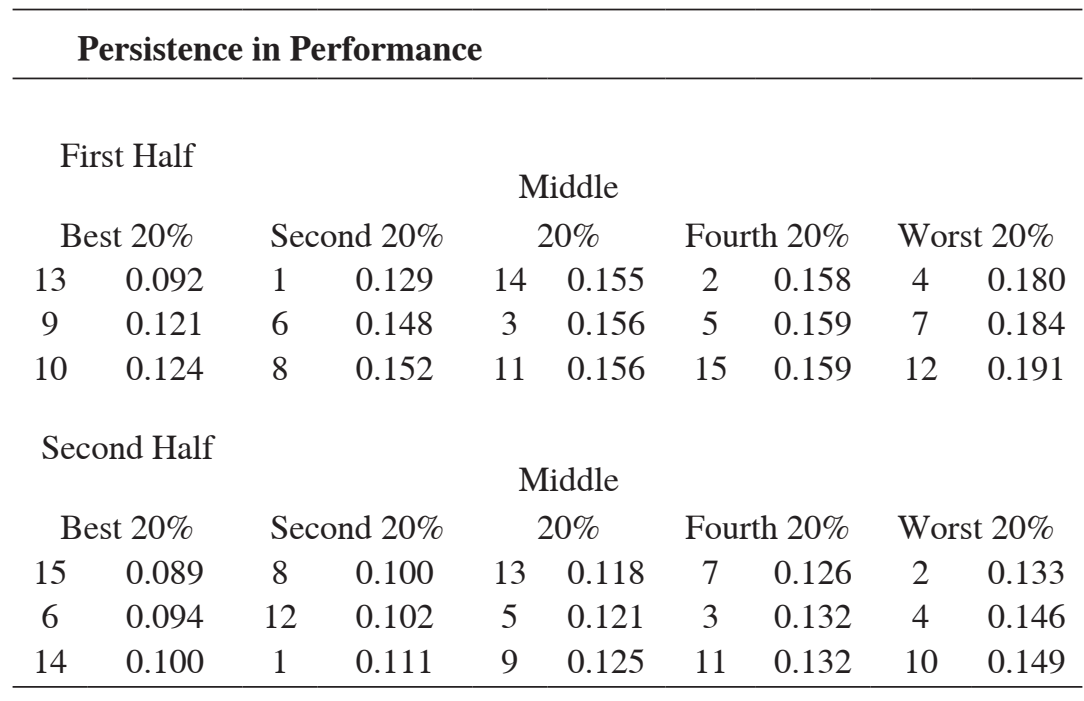

Participants are ranked with respect to their average absolute forecast errors in the first and second halves of the sample period. They are divided into five quintiles of $20 \%$ or three. The first column of each quintile provides the participant's code and the second column his/her average absolute forecast error. 


\section{Behavioral Hypotheses}

Extrapolation Bias. To determine whether the participants as a group extrapolate from the past, the following regression is run:

$$
\mathrm{FR}_{\mathrm{t}}=\mathrm{c}+\mathrm{dR} \mathrm{R}_{\mathrm{t}-1}+\mathrm{e}_{\mathrm{t}}
$$

The result is close to borderline levels of significance to reject the null hypothesis " $c=0$ " ( $\mathrm{F}=2.35$, $\left.\operatorname{sig}(F)=0.134, R^{2}=0.063\right)$. If $F R$ is defined to be the average, rather than median, forecast return, the relationship turns out to be stronger: The null hypothesis " $\mathrm{c}=0$ " can be rejected at a $5 \%$ level $(\mathrm{F}=4.73$, $\left.\operatorname{sig}(F)=0.037, R^{2}=0.119\right)$. This is interesting because it is difficult to obtain a reliable estimate of the market return from experts' forecasts, but the opposite is possible: The forecasts of the experts can be estimated from the previous month's market return. Given that the first order autocorrelation in a monthly return series over the sample period is insignificantly negative at -0.172 , there is evidence of unwarranted extrapolation from the past. Around $12 \%$ of the variation in average forecasts can be explained by the previous period's return. ${ }^{(9)}$ These results are consistent with the hypothesis that analysts, as a group, extrapolate from the previous month's return. Further analysis by sub-periods suggests a decrease in the extrapolation tendency in the latter part of the sample. ${ }^{(10)}$

A similar regression is separately run for each of the 14 high-attendance-participants to find out individual tendencies to extrapolate from the past:

$$
F R_{t}^{i}=c^{i}+d^{i} R_{t-1}+e_{t, i}
$$

The results, presented in Table 3, indicate that the coefficient of the previous month's return is positive for 13 of 14 participants, significant at $10 \%$ for two and at 5\% for an additional three. Interestingly, for the best performer (according to minimum average absolute forecast error criterion), the null hypothesis " $\mathrm{d}=0$ " cannot be rejected at any conventional significance level, implying that he has not extrapolated from the past. Moreover, four of the five participants who exhibited significant tendencies to extrapolate from the past entered Equation 2 (the forecast ability test) with a negative sign. These findings are consistent with the hypothesis that extrapolation and poor performance coincide. A crosssectional regression of the $\mathrm{b}^{\mathrm{i}}$ coefficients on $\mathrm{d}^{\mathrm{i}}$ coefficients turned out a significant inverse relationship $\left(\mathrm{n}=18, \mathrm{~F}=3.99, \operatorname{sig}(\mathrm{F})=0.063\right.$, the Pearson correlation between $\mathrm{b}^{\mathrm{i}}$ and $\mathrm{d}^{\mathrm{i}}$ is $-0.447, \mathrm{R}^{2}=0.20$, implying that $20 \%$ of the variation in performance could be attributed to extrapolation bias).

An interesting question arises here: Can these findings of extrapolation be in fact a reflection of wishful thinking? Most, if not all, of the survey participants are active traders in the market. It is likely that when the market has moved up in the recent past most active traders have long positions (not necessarily vice versa, as short positions on the ISE were practically infeasible over the sample period). Hence, wishful thinking may be as well a potential explanation of these findings as extrapolation. Unfortunately, however, the coverage of the Reuters' survey does not enable us to differentiate between the two alternative explanations. To do this, the participants' transactions data are needed which is unlikely to be available. However, further inspection suggests that extrapolation bias is not significant when the previous month's return is negative (see below), which indirectly supports the "wishful thinking" explanation. 
Table 3

Test of Extrapolation Bias by the Significance of Rejecting the Null Hypothesis " $d$ ' $=0$ " in the Regression Equation $F R_{t}^{i}=c^{i}+d^{i} R_{t-1}+e_{t, I}$

\begin{tabular}{|c|c|c|c|c|c|c|}
\hline Participant & $\mathbf{n}$ & $c^{\mathrm{i}}$ & sig (c) & $d^{i}$ & $\operatorname{sig}(d)$ & R-sqrd \\
\hline 1 & 35 & 0.341 & $0.045^{* *}$ & 0.027 & $0.008 * *$ & 0.116 \\
\hline 2 & 22 & 0.254 & 0.254 & 0.062 & $0.015^{* *}$ & 0.065 \\
\hline 3 & 31 & 0.243 & 0.188 & 0.037 & $0.039 * *$ & 0.059 \\
\hline 4 & 34 & 0.012 & 0.948 & 0.090 & $0.000 * *$ & 0.000 \\
\hline 5 & 33 & 0.088 & 0.627 & 0.075 & $0.000 * *$ & 0.008 \\
\hline 6 & 26 & 0.327 & $0.103^{*}$ & 0.040 & $0.021 * *$ & 0.107 \\
\hline 7 & 27 & 0.442 & $0.021 * *$ & 0.073 & $0.003 * *$ & 0.196 \\
\hline 8 & 25 & 0.097 & 0.643 & 0.055 & $0.013 * *$ & 0.009 \\
\hline 10 & 31 & 0.012 & 0.947 & 0.072 & $0.000 * *$ & 0.000 \\
\hline 11 & 26 & 0.332 & $0.098 *$ & 0.041 & $0.011 * *$ & 0.110 \\
\hline 12 & 27 & 0.394 & $0.042 * *$ & 0.076 & $0.000 * *$ & 0.155 \\
\hline 13 & 32 & 0.030 & 0.87 & 0.028 & $0.006 * *$ & 0.001 \\
\hline 14 & 33 & -0.116 & 0.519 & 0.076 & $0.000 * *$ & 0.014 \\
\hline 15 & 30 & 0.138 & 0.467 & 0.077 & $0.000 * *$ & 0.019 \\
\hline Median & 37 & 0.251 & 0.134 & 0.056 & $0.000 * *$ & 0.063 \\
\hline \multicolumn{7}{|c|}{ Selected Participants with lower attendance } \\
\hline 9 & 18 & 0.296 & 0.234 & 0.042 & $0.040 * *$ & 0.087 \\
\hline 16 & 14 & 0.370 & 0.193 & -0.003 & 0.876 & 0.137 \\
\hline 17 & 16 & -0.208 & 0.440 & 0.054 & $0.000 * *$ & 0.043 \\
\hline 18 & 10 & 0.619 & $0.057 *$ & -0.049 & $0.000 * *$ & 0.383 \\
\hline
\end{tabular}

$\mathrm{n}$ is the number of months. $\mathrm{d}^{\mathrm{i}}$ is participant i's coefficient on previous month's return. $\operatorname{Sig}(\mathrm{d})$ is the significance level of rejecting the null hypothesis " $\mathrm{d}^{\mathrm{i}}=0$ ". R-sqd is the ratio of variation in participant $\mathrm{i}$ 's forecasts explained by $\mathrm{R}_{\mathrm{t}-1}$ to total variation

Systematic Optimism Bias. The time-series mean of average (median) forecast error is $+3.8 \%(+4.0 \%)$, both significant at a $10 \%$ level. In other words, the mean (median) forecast monthly return was $+5.6 \%$ $(+5.8 \%)$, while the mean realized return was merely $+1.8 \%$ during the sample period. This indicates that the forecasters participating in the Reuters survey had, as a group, overestimated the ISE-100 index return, consistent with the systematic optimism bias.

This finding is quite important. It suggests that the systematic optimism bias is not confined to only analysts' earnings forecasts, but is a more general phenomenon. Moreover, as the forecasts were made for the market index, which consists of 100 stocks, it is unlikely that agency issues are involved here. Hence, the agency issues referred to as the likely reason underlying optimism bias in the extant literature on forecasts involving individual stocks fail to account for this finding. Although the fact that all of the participants were employed in the investments sector desiring the market to be attractive may suggest another type of agency issue; this is clearly different and far less direct in effect. A more appropriate explanation may be wishful thinking. 
Easterwood and Nutt (1999), differentiating between reaction to positive and negative information, document that analysts under react to negative information, but overreact to positive information (which they summarize as "systematic optimism"). In a similar manner, our data set allows us to compare the extent of the extrapolation bias with respect to the nature of the information (previous month's return). Employing a simple approach, data are partitioned by the sign of the realized return in the previous month, and Equation 3 is estimated separately for subgroups of positive and negative monthly returns, respectively. The results suggest that extrapolation bias is significant when the previous month's return is positive $\left(n=21, d=+0.507, F=6.58, \operatorname{sig}(F)=0.019, R^{2}=0.257\right)$, but insignificant when the previous month's return is negative $\left(n=16, d=+0.157, F=0.36, \operatorname{sig}(F)=0.561, R^{2}=0.025\right)$. That is, survey participants tend to extrapolate positive rather than negative price movements.

On the other hand, the constant in Equation 3 is insignificant when the previous month's return is positive $(c=0.020, p=0.299)$, but significant when the previous month's return is negative $(c=0.063$, $\mathrm{p}<0.001$ ). That is, when the ISE-100 index falls, optimism bias dominates the extrapolation effect; and when the index rises, extrapolation captures most part of the optimism effect. These findings reiterate the asymmetry, noticed by Easterwood and Nutt (1999), in analysts' reactions due to the nature of information and enhance their conclusion in favor of "systematic optimism" rather than "systematic misreaction" (extrapolation).

A comparison of mean forecast errors on sub-samples conditioned by the sign of the previous month's return provides the following results: When the ISE-100 index rose in month $\mathrm{t}-1$, the mean forecast error for month $\mathrm{t}$ is +0.046 . When it fell in month $\mathrm{t}-1$, the mean forecast error for month $\mathrm{t}$ is +0.033 (the difference is insignificant). That is, the forecasting performance does not differ much, following rises or falls.

A further detail is that, unlike extrapolation bias, the degree of optimism bias is not negatively correlated with forecasting performance: The cross-sectional correlation between $c^{i}$ and $b^{i}$ was insignificant at $+0.063(\mathrm{p}=0.805)$. Note that this is not a byproduct of sample-specific returns as abnormal returns over our sample period were insignificant.

\section{Hypotheses in the Noisy Rational Expectations Literature}

Heterogeneous Expectations. MacDonald and Marsh (1996) measure the significance of individual differences as follows:

$$
\mathrm{FR}_{\mathrm{t}}^{\mathrm{i}}=\mathrm{X}_{\mathrm{t}}+\mathrm{g}^{\mathrm{i}}+\mathrm{u}_{\mathrm{t}}^{\mathrm{i}}
$$

where $\mathrm{X}_{\mathrm{t}}$ is the component based on public information common to all participants, $\mathrm{g}^{\mathrm{i}}$ is the individual (idiosyncratic) effect, and $u_{t}^{i}$ is an individual random disturbance term, which could occur due to measurement errors (such as strategic behavior). The average forecast is:

$$
\mathrm{FR}_{\mathrm{t}}^{\mathrm{A}}=\mathrm{X}_{\mathrm{t}}+\mathrm{g}^{\mathrm{A}}+\mathrm{u}_{\mathrm{t}}^{\mathrm{A}}
$$

Normalizing such that $\mathrm{g}^{\mathrm{A}}$ equals zero and subtracting (5) from (4), we obtain:

$$
\mathrm{FR}_{\mathrm{t}}^{\mathrm{i}}-\mathrm{FR}_{\mathrm{t}}^{\mathrm{A}}=\mathrm{g}^{\mathrm{i}}+\left(\mathrm{u}_{\mathrm{t}}^{\mathrm{i}}-\mathrm{u}_{\mathrm{t}}^{\mathrm{A}}\right)
$$


The individual effects (biases) $\mathrm{g}^{\mathrm{i}}$ may then be measured by the significance of a nonzero $\mathrm{g}^{\mathrm{i}}$ without specifying the common information set $X_{t}$. It is possible that heterogeneity follows both from individual effects and idiosyncratic coefficients on a component, $I_{t}$, of public information set (i.e., each forecaster placing different weights on some element of public information set). Then, $\mathrm{FR}_{t}{ }_{\mathrm{i}}=\mathrm{X}_{\mathrm{t}}+\mathrm{g}^{\mathrm{i}}+\beta^{\mathrm{i}} \mathrm{I}_{\mathrm{t}}+\mathrm{u}_{\mathrm{ti}}$ where $\beta^{\mathrm{i}}$ is the weight that participant i places on information $\mathrm{I}_{\mathrm{t}}$. The equivalent for Equation 6 (using the notation in MacDonald and Marsh) is then:

$$
\mathrm{FR}_{\mathrm{t}}^{\mathrm{i}}-\mathrm{FR}_{\mathrm{t}}^{\mathrm{A}}=\mathrm{g}^{\mathrm{i}}+\left(\beta^{\mathrm{i}}-\beta^{\mathrm{A}}\right) \mathrm{I}_{\mathrm{t}}+\left(\mathrm{u}_{\mathrm{t}}^{\mathrm{i}}-\mathrm{u}_{\mathrm{t}}^{\mathrm{A}}\right)
$$

Under this formulation, individual biases $\left(\mathrm{g}^{\mathrm{i}} \neq 0\right)$ and the idiosyncratic interpretation of public information $\left(\beta^{\mathrm{i}}-\beta^{\mathrm{A}} \neq 0\right)$ can be jointly tested.

Equation 7 is estimated by OLS for each of the 14 high-attendance participants. Lagged return $\mathrm{R}_{\mathrm{t}-1}$ of the ISE-100 index is used as the information term $\mathrm{I}_{\mathrm{t}}$.

The results, reported in Table 4, below, indicate five significant (at a 10\% level) individual biases and two significant (at $10 \%$ level) idiosyncratic interpretations of the common information $\left(\mathrm{R}_{\mathrm{t}-1}\right)$. Participants 4, 5 and 14 (1 and 13) are more optimist (pessimist) than the average. Participant 7 places more weight on $\mathrm{R}_{\mathrm{t}-1}$ than the average does, while participant 14 employs a contrarian view. Compared

Table 4

Test of Individual Differences and Idiosyncratic Interpretation of Common Information

\begin{tabular}{cccccc}
\hline Participant & $\mathrm{n}$ & $\mathrm{g}^{\mathrm{i}}$ & $\operatorname{sig}($ reject"gi $=0 ")$ & $\beta^{\mathrm{i}}-\beta^{\mathrm{A}}$ & $\begin{array}{c}\text { sig(reject" } \beta^{\mathrm{i}}- \\
\left.\beta^{\mathrm{A}}=0 "\right)\end{array}$ \\
\hline 1 & 35 & -0.027 & $0.015^{* *}$ & 0.038 & 0.676 \\
2 & 22 & -0.001 & 0.956 & 0.05 & 0.74 \\
3 & 31 & -0.016 & 0.276 & 0.051 & 0.666 \\
4 & 34 & 0.036 & $0.022^{* *}$ & -0.116 & 0.369 \\
5 & 33 & 0.023 & $0.07 *$ & -0.078 & 0.451 \\
6 & 26 & -0.015 & 0.253 & 0.071 & 0.512 \\
7 & 27 & 0.015 & 0.418 & 0.281 & $0.061^{*}$ \\
8 & 25 & -0.008 & 0.692 & -0.072 & 0.629 \\
10 & 31 & 0.019 & 0.174 & -0.129 & 0.27 \\
11 & 26 & -0.004 & 0.765 & 0.119 & 0.34 \\
12 & 27 & 0.020 & 0.176 & 0.173 & 0.192 \\
13 & 32 & -0.027 & $0.011^{* *}$ & -0.132 & 0.135 \\
14 & 33 & 0.021 & $0.03 * *$ & -0.191 & $0.022^{* *}$ \\
15 & 30 & 0.022 & 0.134 & 0.008 & 0.945 \\
\hline
\end{tabular}

Individual differences are tested by the significance of rejecting "gi $=0$ " in Equation 8. Idiosyncratic interpretation of common information is tested by the significance of rejecting " $\beta \mathrm{i}-\beta \mathrm{A}=0$ " in Equation 7. gi is the sample estimate of participant i's individual bias; sig (reject "gi $=0$ ") is the level of significance for rejecting the null hypothesis that $g i=0 . \beta \mathrm{i}-\beta \mathrm{A}$ is the sample estimate of the difference of individual i's coefficient on information term from the average coefficient; sig (reject " $\beta \mathrm{i}-\beta \mathrm{A}=0$ ") is the level of significance rejecting the null hypothesis that the difference is zero. (**) significant at $5 \%$ level, (*) significant at $10 \%$ level. 
to the results reported by MacDonald and Marsh (1996), ${ }^{(1)}$ these imply a slightly lower degree of heterogeneity, which should not be surprising as one would expect the Turkish stock market to have less heterogeneous participant structure than the global foreign exchange markets.

The Relation between Dispersion in Expectations and Volatility and Trading Volume. The dispersion of expectations is measured by the cross-sectional standard deviation of forecast returns in a month across participants. Two regressions of volatility and trading volume, respectively, are run on the dispersion of expectations, to test hypotheses in the literature that link trading volume and volatility with disagreement of prior opinions. Volatility in month $t$ is measured in two ways: i) absolute value of monthly index return, and ii) standard deviation of daily returns in a month. As volume has exhibited an upward time-trend over the sample period and is positively related to returns, we use volume figures adjusted for trend and return. ${ }^{(12)}$

The results suggest that there is no significant relationship between the dispersion of forecasts and volatility $(\mathrm{F}=0.39, \operatorname{sig}(\mathrm{F})=0.53$ with monthly absolute returns; and $\mathrm{F}=0.93, \operatorname{sig}(\mathrm{F})=0.34$ with standard deviation of daily returns). There is no significant relationship between dispersion of forecasts and the monthly trading volume, adjusted both for trend and volatility, either $(F=0.03$, sig $(F)=0.95) .{ }^{(13)}$ These findings are not in line with those of MacDonald and Marsh (1996) on currency forecasters. They concluded that the heterogeneity of forecasts was a factor determining trading volume.

Although reading too much into this survey data should be avoided as it represents only a small proportion of market participants, these results do not suggest the heterogeneity of prior expectations as the factor driving volume and volatility. It may be new information arrivals.

The Role of Market Price as Aggregator of Private Information. A direct test of the hypothesized role requires the use of multiple forecasts taken at different points in time for the same terminal value. The mere possible test with the limited coverage of this survey data is to check the relationship between forecast errors in month $\mathrm{t}-1\left(\mathrm{FE}_{\mathrm{t}-1}=\mathrm{FR}_{\mathrm{t}-1}-\mathrm{R}_{\mathrm{t}-1}\right)$ and forecasts $(\mathrm{FR})$. A positive relationship would be inconsistent with the role of market price as the aggregator of private information, as it would suggest that participants insist on their private beliefs (expecting the market to eventually reverse) rather than revise them in line with the market price. No-relation would be consistent with an assumption that participants, as a group, conform to the information delivered by market price, whereas a negative relationship would suggest that analysts employ some form of an error correction model. The analysis is clouded, however, by our previous finding that forecasts extrapolate previous realized returns, which are a major determinant of forecast errors (in other words, extrapolation bias already induces a negative relationship between past forecast errors and forecasts). We therefore remove the effect of extrapolation bias on forecasts, and seek a relationship between residual forecasts and past forecast errors:

$$
\operatorname{Res} \cdot \mathrm{FR}_{\mathrm{t}}=\mathrm{a}+\mathrm{b} \mathrm{FE}_{\mathrm{t}}+\mathrm{e}_{\mathrm{t}}
$$

where Res.FR is the residual of a regression of median forecast on previous month's realized return $\left(\mathrm{R}_{\mathrm{t}-1}\right)$; in other words forecasts corrected for extrapolation bias.

The result from the estimation of Equation 8 suggests an insignificant negative relation between the forecast error for month $\mathrm{t}-1$ and forecasts for month $\mathrm{t}$ (standardized $\mathrm{b}=-0.149, \operatorname{sig}(\mathrm{b})=0.387, \mathrm{~F}=0.77)$. ${ }^{(14)}$ This is consistent with the assertion that analysts place greater weight on the information they derive from 
the market price, such that they conform to the information delivered by the market price innovation rather than stick to their priors.

\section{CONCLUSIONS}

The main conclusions from the results presented in the previous section are as follows:

The participants of the survey conducted by Reuters Turkey news service exhibited no significant ability to predict monthly returns of the ISE-100 index. The distribution of performance was similar to, even worse than, what would be obtained under pure chance. There is little evidence of performance correlated across time. None of the participants' forecasts performed better than those produced by a simple random walk model. These results are consistent with the implications of efficient markets theory.

The participants of the survey analyzed in this study, as a group, exhibited significant biases of optimism and extrapolation, unjustified by the behavior of realized returns. The degree of being vulnerable to extrapolation bias was positively correlated with forecast errors. Individual differences in forecast performance can partly be explained by the degree of this bias. Optimism bias, which has been traced to agency issues, was documented in a context of index return forecasting where agency issues were not present. A potential explanation could be wishful thinking. The asymmetry observed in extrapolating positive vs. negative past returns preferred optimism bias over systematic extrapolation (misreaction). The asymmetry, together with the fact that short positions are very costly to build in ISE, supported "wishful thinking" as the more plausible explanation.

The participants' forecasts exhibited a moderate degree of heterogeneity, which would support the use of heterogeneous expectations models in market equilibrium dynamics on the Turkish stock market. However, the degree of the heterogeneity in the forecasts did not seem to drive market volume and volatility, though we cannot generalize this finding too far, as the survey participants constituted only a small proportion of the market. Finally, the participants seem to place greater weight on the information they derive from market price than on their priors.

One contribution of this study might be to confirm the significance of previously documented behavioral biases in analysts' expectations in a different real-life context of stock index forecasting in an emerging market. It seems that the small predictive ability of forecasters is more than wiped out by behavioral biases to turn out worse performance than a simple random walk model. For real-life investors, especially the audience of analysts, it is hoped this study sheds light on how analysts' views should be interpreted and what is to be taken out of them.

\section{NOTES}

1. The raw data of participants and their forecasts can be obtained both from the author and from Reuters Turkey News Service (contact Ms. Güzin Övünç, who conducted the surveys and reported them as a news item, at guzin.ovunc@ reuters.com.tr). 
2. There was an interruption for two months between Dec. 2003 and Jan. 2004 due to a temporary leave taken by the Reuters News Service reporter conducting the survey. This is unlikely to affect results of the study, nor to alter the treatment of data.

3. This is done with the consent of the participant, expectedly with the approval of the management of the participant's institution. Three participants refused this and withdrew from the survey.

4. This provides us a unique opportunity to evaluate the impact of publicity on strategic behavior. To the extent that publicity eliminates strategic behavior, we can assess the magnitude of measurement errors due to strategic behavior by comparing the behavior of mean relative to median forecast errors in these two sub-periods. Note that absolute forecast errors are a positive function of the conditional return volatility, and the reduction in forecast errors in the post-publicity period is due to lower volatility.

5. The first year in the sample, as a post-crisis period, was especially difficult to forecast. I believe that the relationship between forecast errors and volatility captures most of the improvement in the later part. Another factor driving the improvement in the later part, however, might be that the index exhibited more trending behavior in the later part than in the earlier part.

6. The regression is also repeated for illustrative purposes for other participants with attendance rates above $25 \%$.

7. Two of the lower-attendance participants provided more successful forecast performances with mean forecast error at $6.1 \%$, and one having a positive $\mathrm{b}^{\mathrm{i}}$ coefficient significant at a $10 \%$ level.

8. One can raise an issue against the use of mean absolute error as a forecasting performance criterion, especially in the context of stock markets. However, I believe such a critique would not apply to this survey because the participants were evaluated by the closeness of their forecasts to actual closing level. For example, Reuters once offered an award to the closest forecast to year-end index level.

9. Muradoğlu (2002) debates the hedging tendency for forecasts extrapolating past trends with skewed interval estimates on experimental subjects, put forward by DeBondt (1993). Since Reuters data consist of only point forecasts, it is unfortunately impossible to test the hedging tendency in this study.

10. The interim results, which suggested a stronger degree of extrapolation bias, were presented at the MFS conference in July 2004 and shared with Reuters Turkey News Service via an executive summary, which Reuters used in a survey evaluation. As a result of such disclosure, sort of a "sensitivization effect" might have played a role in the reduction of the degree of this bias.

11. See Tables 1 and 2 on pp. 670-671.

12. The estimation of regression $E\left(V_{t}\right)=a+b_{1} t+b_{2} R_{t}$ over the sample period provided the following results: $a=2026.5(p<0.001), b_{1}=124.2(p<0.001), b_{2}=8030.4(p<0.001)$. In the analysis of volume vs. expectation dispersion relationship, we therefore used $\mathrm{V}_{\mathrm{t}}-\mathrm{E}\left(\mathrm{V}_{\mathrm{t}}\right)$. 
13. It is worth noting that the regression of raw volume on dispersion suggested a significantly negative relationship. However, it is nothing more than a by-product of increasing volume and decreasing volatility over the sample period. This justifies our use of trend- and return-adjusted volume series.

14. Results with unadjusted forecasts suggest a negative relationship between last month's forecast error and next month's forecast return at borderline levels of significance (correlation=-0.246, $\mathrm{p}=0.149$ ). However, this is merely a reflection of extrapolation bias.

\section{REFERENCES}

Bollen, N.P.B. and Busse, J.A. (2004). "Short-term Persistence in Mutual Fund Performance," The Review of Financial Studies, 18(2): 569-597.

Brock, W., Lakonishok, J., and LeBaron, B. (1992). "Simple Technical Trading Rules and the Stochastic Properties of Stock Returns," Journal of Finance, 47: 1731-1762.

Cho, J. and Krishnan, M. (2000). "Prices as Aggregators of Private Information: Evidence from S\&P500 Futures Data," Journal of Financial and Quantitative Analysis, 35: 111-126.

Cowles, A. (1934). “Can Stock Market Forecasters Forecast?” Econometrica, 1:309-324.

Dechow, P.M. and Sloan, R.G. (1997). "Returns to Contrarian Investment Strategies: Tests of Naïve Expectations Hypothesis," Journal of Financial Economics, 43: 3-27.

DeBondt, W.F.M. (1993). "Betting on Trends: Intuitive Forecasts of Financial Risk and Return," International Journal of Forecasting, 9: 355-371.

Easterwood, J.C. and Nutt, S.R. (1999). "Inefficiency in Analysts' Earning Forecasts: Systematic Misreaction or Systematic Optimism?” Journal of Finance, 54:1777-1794.

Fama, E.F. (1970). "Efficient Capital Markets: A Review of Theory and Empirical Work," Journal of Finance, 25: 383-420.

Fama E.F. and French, K.R. (1988). "Permanent and Temporary Components of Stock Prices,” Journal of Political Economy, 96(2): 246-273.

Foster, F.D. and Viswanathan, S. (1996). "Strategic Trading When Agents Forecast the Forecasts of Others," Journal of Finance, 51: 1437-1470.

Grossman S. and Stiglitz, J.E. (1980). "On the Impossibility of Informationally Efficient Market," American Economic Review, 70: 393-408.

Grundy, B.D. and McNichols, M. (1989). "Trade and Revelation of Information through Prices and Direct Disclosure," Review of Financial Studies, 2: 495-526. 
Hartzmark, M.L. (1991). "Luck versus Forecast Ability: Determinants of Trader Performance in Futures Markets," Journal of Business 64: 49-73.

Kyle, A.S. (1985). “Continuous Auctions and Insider Trading,” Econometrica, 53: 1315-1335.

Lakonishok, J., Shleifer, A, and Vishny, R.W. (1994). "Contrarian Investment, Extrapolation and Risk," Journal of Finance, 49: 1541-1578.

MacDonald, R. and Marsh, I.W. (1996). "Currency Forecasters Are Heterogeneous: Confirmation and Consequences," Journal of International Money and Finance, 15: 665-685.

Muradoğlu, G. (2002). “Portfolio Managers' Forecasts of Risk and Return: Are There Predictable Forecast Errors?” Journal of Forecasting, 21(6): 395-416. 